\title{
End of Life Care in Elderly: Family Experiences
}

\author{
Retno Indarwati, Rista Fauziningtyas, Sylvia Dwi Wahyuni, Elida Ulfiana \\ Division of Gerontological Nursing \\ Faculty of Nursing, Universitas Airlangga \\ Surabaya, Indonesia \\ e-mail: rfauziningtyas@gmail.com
}

\begin{abstract}
Mostly, death occurs due to aging, while the rest because of illness. In palliative care, Indonesian elderly with a chronic disease more likely to stay at home with their families until the death. These conditions give a unique experience to the family when taking care of elderly at the end of their life. This study was aimed to explore the family experiences in taking care of the elderly at the end of life. This study used a qualitative method with a phenomenological approach. It was in-depth interview with semi-structured questions. The sampling technique was purposive sampling with inclusion criteria at Puskesmas Mulyorejo, Surabaya, Indonesia. A total of 4 family carers were recruited, and ten individuals were got involved in an in-depth interview. Five themes were revealed, including response, barriers, coping mechanism, the hope of family member, and the needs of health care. Taking care of the elderly at the end of life could bring a negative response to the family. So, in some cases the family need properly preparation and some help from the health workers.
\end{abstract}

Keywords - family, end-of-life-care, elderly, experiences, palliative

\section{INTRODUCTION}

Every year as many as $1 \%$ of population in the world died [1]. Mostly, death occurs due to aging whether they are sick or not. The pattern of illness in elderly is a limited life of chronic disease, such as heart disease, chronic obstructive pulmonary disease, diabetes, cancer and dementia [2]. Despite many deaths occur at elderly, the policy on special needs towards the end of life is still none [2]. Elderly with chronic disease more likely to stay at home with their families. These conditions gave a unique experience to family when they provide a caring for elderly at the end of their life. Until now, that experience still unknown.

SUSENAS (Survey Sosial Ekonomi Nasional) data showed the number of elderly households as much as 16.08 million or $24.50 \%$ of all households in Indonesia. Elderly households are households with family members age over 60 years at least one person. Elderly in Indonesia reached 20.24 million, equivalent to $8.03 \%$ of the entire population of Indonesia 2014 [3]. The data collected by the Pusat Data Informasi in 2014 showed that 10 top disease is a chronic disease of the elderly. In the elderly aged over 75 years is the most prevalent diseases of stroke and other cardiovascular diseases [4]. Diseases that occur in the elderly cause dependence elderly in care giver. Data elderly dependency ratio of 12.71 . This shows that every 100 people of productive responsible to \pm 13 elderly. Comparison of dependence of elderly women (13.59) is higher than men (11.83). A total of $42.32 \%$ of elderly living with extended family. Usually they stay with the child / daughter and grandchildren, or with children / in-law and parents / in-laws. A Senior High Schoolll portion that is $26.80 \%$ of elderly living with the nuclear family, while staying just a couple of $17.48 \%$ [3].

Death can be sudden or predictable death. The final determination of human life is very difficult to do. But this time, the determination of the end of life may be determined based on the research and the clinical condition of the client [1], [2]. End of life is the condition of a person approaching the end of life counted within 12 months. It also includes a person whose death is near (is expected within a few hours or days) and with conditions: 1. chronic, progressive and incurable; 2. Frailty and the conditions that lead to death within a period of one year; 3 . Acute Conditions at risk of sudden death; 4. The life-threatening condition caused by sudden catastrophic events [1], [5].

The end of life associated with palliative care. In traditionally, palliative care concern to cancer patients. However, according to the WHO, the elderly with cardiovascular disease are more likely to die than cancer patients. Elderly who reach the end of life often found also suffering from multiple debilitating diseases (such as dementia, osteoporosis, and arthritis) in a long time [1], [2], [5]. Such conditions require more complex care and concern for caregivers.

The caregivers of elderly in Indonesia are mostly their own families. Because the value and guidance of religion in Indonesia put the elderly to be respected, appreciated and it is a must for the family to makes them happy in life [6]. However, the elderly at the end of life sometimes can be the "burden" for the family. Disease suffered by one family member will affects the family. It will appear mixed response on the family, both positive and negative responses [7]. The family has an important role in the care of the elderly at home. Special preparations need to be done by the family to live with 
the elderly at the end of life. The preparation includes the physical and mental preparation. Mental preparation could done by adapting to changing conditions such a motoric paralyzed that requires total care assistance, or elderly who unable to recognize the other family members (in dementia). Physical preparation is environmental modification that provide comfort and safety for elderly [8].

Families that do not make a good preparation can disrupt family coping mechanisms. This will lead to conflict within the family members [7]-[9]. Based on several studies, there is a change in the "normal life" family and incompetence feel when caring for elderly relatives at the end of life. Increased need of care, stress, experience of facing death and conditions uncertain future will be experienced by every member of the family with the elderly at the end of life [9]. The initial data which taken in 2015 in Puskesmas Mulyorejo, Surabaya was known that 8 care giver of the elderly with Frailty syndrome feel unstable emotionally. Sometimes they feel happy when caring for the elderly, but at the other times they feel tired and bored.

Family experiences in caring the family members with palliative conditions are still not known well because not much research reveal about this condition [9]. Since the experience is unique, it couldn't describe through quantitative research [8]. Each family will get a different experience depending on the situation and illness in the elderly. Therefore, this study aimed to explore family experiences in taking care of the elderly at the end of life.

\section{METHODS}

This study has approved by the Ethical Comittee of Health Research, Faculty of Nursing, Universitas Airlangga, Surabaya, Indonesia. This was a qualitative research with phenomenological approach. The population in this study were all family member who was taking care of elderly in their end of life at Puskesmas Mulyorejo, Surabaya, Indonesia. Participants gained by purposive sampling technique and were selected based on the following inclusion criteria: 1) every members of family who lived together with elderly, 2) aged> 18 years 3) could communicate in Bahasa (Indonesian language), and 4) were willing to become a participant by filled out and signed informed consent after read it carefully and got an explanation about the purpose of study by the researcher. In order to respect for participant's right, they could refuse to participate anytime. Since the researcher have responsibility to the emotional effect of participants, then after interview the researcher gave a consultation session to the participants.

In collecting data, researcher used voice recorder, the list of semi-structured questions, and taking some field notes (Field Note) to record non-verbal response and condition that might affect the interview process and the researcher's own self as a research instrument. In-depth interview with semistructured questions used a kind of open questions that gave participants a chance to express their experience in their own words related to taking care of elderly in end of his life at home. This research used nine steps of interpretation data according to Colaizzi [10] because the steps were quite simple, clear and detail.

Interviews were audio-recorded and transcribed in verbatim. First, transribed verbatim was wrote in Bahasa and then translated into English. An inductive thematic analysis was used to gain family experiences as care giver in elderly in end of his life at home. The inductive thematic analysis of the interviews was made by one researcher. Transcripts were analysed for content line by line and codes were noted in the margins, creating a label for each sentence. As codes emerged, they were compared with codes from earlier interviews to determine similarities and differences. The codes were grouped and labelled using broader categories and themes.

To ensure the validity of data we made a system. These system was one interview independently analysed by two researchers. This interview was discussed with a third researcher. The researchers worked towards a consensus in interpretation, like peer review. The transparency of the analytical process and verifiability of the research was enhanced by using memos made by the researchers to explain interpretations and conclusions. Coding and development of categories were mainly carried out by the first researcher, then peer review was performed by the second researcher.

\section{RESULTS}

\section{Participants}

Ten individuals were indepth-interviewed from a total of 4 families. Every participant was interviewed range $30-60$ minutes. Interviews were conducted separately face to face, so that participants can tell the opinion honestly. The research found a variety of occupation of family members were include employee, student, driver and housewife (Table I).

TABLE I. DEMOGRAPHIC OF PARTICIPANTS

\begin{tabular}{|c|c|c|c|c|c|c|c|}
\hline No. & Pseudonim & Gender & Age & Education & Relation to Elderly & Occupation & Health Status of Elderly \\
\hline 1 & P1.1 & Male & 21 & Senior High School & Child & Student & Suspect Demensia (Female) \\
\hline 2 & $\mathrm{P} 1.2$ & Female & 56 & Bachelor & Wife/Couple & Housewife & \\
\hline 3 & $\mathrm{P} 2.1$ & Female & 49 & Senior High School & Child & Housewife & CVA and \\
\hline 4 & $\mathrm{P} 2.2$ & Male & 56 & Senior High School & Child in law & Driver & (Female) \\
\hline 5 & $\mathrm{P} 2.3$ & Female & 18 & Senior High School & Grand Child & Student & \\
\hline 6 & P3.1 & Male & 64 & Bachelor & Husband/Couple & Employee & Ca Mammae \\
\hline 7 & P3.2 & Female & 21 & Senior High School & Child & Student & (Female) \\
\hline 8 & P3.3 & Male & 20 & Senior High School & Child & Student & \\
\hline 9 & $\mathrm{P} 4.1$ & Female & 47 & Senior High School & Niece & Housewife & Ca Lung (Male) \\
\hline 10 & P4.2 & Male & 49 & Senior High School & Niece in law & Employee & \\
\hline
\end{tabular}




\section{Themes}

We identified five themes including respons, barriers, coping mechanism, hope of family member, and needs of elderly to health care.

1. Respons of each family members

This theme encompessed 2 subthemes negative and possitive respons when the family members.

Negative response

I feel uncomfort when grand mother defecation on the bed... Verry disgusting (P2.3)

There are 4 respondent feel negative respons when caring elderly in end of life. Not only about defecation but also about the elderly swing mood.

[...],once in the morning she angry to me, she said why you do not wake me up.Then, an hour later, she was crying, because his gown was lost..I'm confused, if my mother do like that .. [..] My mother also angry to our neighbors, thinking sandals taken by our neighbors, but her sandals has been worn.(P1.2)

Positive response

This is my opportunity to take care my parrent. I fell grateful to do it. Although, I couldn't pay his kindness. (P3.1)

6 respondent were show positive respons. They feel happy because its time to serve their parents.

[..] this is my duty to take care my mother, because she is sick..(P2.1)

2. Barriers in caring elderly in end of life

This theme is divided into three sub-themes, including difficulties communicating, finance, health conditions of the elderly. 4 participants found difficulties to communicate to the elderly, 4 participants feel burdened with the cost of medication and treatment and the other 2 feel difficulties adapting to the elderly health conditions.

Communication difficulties

Very difficult to communicate with mother.

Mom sometimes forget what has she said.

She will angry when I remind it. (P1.2)

Finance

My husband is a driver, his earn just enough for our daily needs. Actually, we feel heavy. Thank God there are still relatives who help us. (P2.1)

Condition of elderly

We need two peoples to help my mother bathing and cleaning her room. My mother has big body so it took two people to lift. Whereas, my husband was not every day back home. So sometimes I ask my son. (P2.1)

Uncle often would not eat. Even though I already cook his favorite food, spinach and fried fish. If that's usually because of nausea, is it because of his illness? (P4.2)
3. Coping mechanism of family

This theme was divided into two sub-themes namely adaptive and maladaptive coping mechanisms. 6 participants shows the adaptive coping mechanism and 4 participants used maladaptive coping mechanism.

Adaptive

[..] I see the condition of my wife like that, I feel very sad. But for the sake of my children I must be strong. If they see me sad, they also sad. Pray and tell to God. He will help me. I believe that. (P3.1)

Maladaptive

[..]My mom aften asked me to help clean up grandmother's defecation .. I sometimes straight out of the house. Actually the only reason I came out. I just do not want to help.. (P2.3)

4. Hope of family

This theme was divided into two sub-themes. There are hope for recover and confort.

Recovery

I want mom to recover. Therefore, I deliver mom treatment, even though I had no money. (P2.1)

Comfort

[..] I know uncle was not able to heal, doctors have said the disease has spread. So despite being treated also could not recover. I just hope the uncle could eat well, no pain and no dyspneu (P4.2)

5. Needs in caring elderly in end of life

This theme divided into 3 sub themes., include finance, emotional, and health care.

Finance

When caring uncle we need medical costs, transportation costs also costs for day care. (P4.2)

Emotional

My wife ever wanted to quit treatment. I do also so desperate. But thank God, our children and parents motivate for treatment. (P3.1)

Health Care

Besides the need to eat, I buy medicine at a pharmacy and pay for a doctor. (P2.2)

\section{DISCUSSIONS}

This study explores the family member experiences of end-of-life care for elderly, considering families' response, hope, barriers, needs and coping mechanism. Throughout the findings, there is an underlying theme of conflict. The conflict between family member about the existence of the elderly.

Needs must be prepared by the family is not only a physical need but also emotional needs. Emotional needs required to motivate the elderly to be happy for the rest of his life. In fact, most families still expect the elderly can recovery 
like before. Only one participant who want elderly to be able to live comfortably, free from pain. This can present a burden on the family because the elderly that suffer a chronic diseases is difficult to cure.

Caregiver coping mechanism in the study includes adaptive coping and adaptive coping maladaptive coping of caregivers consists of completing with others, pray and remember God. This mechanism is done so that participants can have a strong willings in caring for the elderly at the end of life. This situation is consistent with the statement and Lazzarus Folkman (1984) that resolving problems with others is a real coping focused on problem-solving efforts to cope with the situation it faces [11].

Maladaptive coping identified in this study is an increase of emotions triggered by the inability of seniors to perform personal hygiene. Maladaptive coping is distressing for the individuals or other persons associated with an individual or a stressful event.

The positive response appeared in the family because there is an awareness that taking care of the elderly is a liability. The obligation in caring for the elderly in this study include the obligation as a daughter. The duty to care for the elderly also may be formed from a moral responsibility towards the parents who embody cultural forms rooted in Indonesia. This is suitable with the characteristics of families in Indonesia. They are very respectful of their parents, and it leads families living with and caring for the elderly until the end [6], [12].

\section{CONCLUSION}

The services needed by the elderly and families in the care of the elderly at the end of life is health care, emotional and financial. The family remains hopeful that the elderly can be cured of the disease and seek to heal for them. When caring for the elderly at the end of life can bring a negative response to the family.

Based on the above conditions of health workers in the Puskesmas Mulyorejo can provide counseling and health education to families about how to care for her elderly end of life. Future studies can use these articles to create a model of end of life care for the elderly at home.

\section{REFERENCES}

[1] General Medical Council, "The GSF Prognostic Indicator Guidance," 2011.

[2] WHO, "Palliative Care for Older People: Better Practices," WHO Reg. Off. Eur., pp. 1-72, 2011.

[3] Badan Pusat Statistik, "Statistik Penduduk Lanjut Usia," 2014.

[4] Kementerian Kesehatan RI, "infodatin-lansia.pdf," 2014.

[5] Commisioning End of Life Care, a c $t$ \& e a r l y, no. June. 2011.

[6] S. G. Setiti, "Pelayanan Lanjut Usia Berbasis Kekerabatan ( Studi Kasus Pada Lima Wilayah Di Indonesia),” pp. 153-167, 2006.

[7] M. R. Friedman, V. R. Bowden, and E. Jones, Family Nursing: Research, Theory, and Practice, 4th ed. Philadhelphia: Lipincot williams \& Wilkins, 2010.

[8] R. H. Widyastuti, J. Sahar, and H. Permatasari, "PENGALAMAN KELUARGA,”pp. 49-57, 2006.

[9] K. I. Stajduhar, "Burdens of family caregiving at the end of life.: EBSCOhost," clin invest Med, vol. 36, no. 3, pp. 121-126, 2013.

[10] J. W. Creswell, Research Design; Qualitative, Quantitative, and Mixed Methods Approach. Los Angeles: SAGE Publication Ltd, 2012.

[11]S. Folkman and R. Lazzarus, Stress Apraisal and Coping. New York: W.B Saunders, 1984.

[12] S. P. Suardiman and S. Iswanti, "Fenomena Lanjut Usia Bertempat Tinggal Di Rumah Anak," 1988. 